\title{
Multiple Sclerosis Treatment with Natalizumab: Analysis of a Hospital-Based Cohort
}

\author{
Tratamento da Esclerose Múltipla com Natalizumab: Análise de Uma Coorte \\ Hospitalar
}

\author{
Ana Teresa CARVALHO ${ }^{1,2}$, Pedro ABREU ${ }^{1,3}$, Maria JOSÉ SÁ Á, $^{1,4}$ \\ Acta Med Port 2014 Jul-Aug;27(4):437-443
}

\section{ABSTRACT}

Introduction: Natalizumab is licensed as monotherapy for relapsing-remitting multiple sclerosis. Since pivotal studies showing natalizumab efficacy, several subsequent studies confirmed the reduction in annualized relapse rate and the slowing of disability progression. Nevertheless, 'real-world' data, namely in Portugal, are still scarce. We intend to report demographic and clinical data of the cohort of patients treated with natalizumab in the multiple sclerosis Clinic of Centro Hospitalar São João, based on daily practice.

Material and Methods: We have conducted a retrospective study of multiple sclerosis patients who had been treated with natalizumab (at least one dose) from January 2007 to May 2013 in our Center. We have gathered information about demography, baseline disease, natalizumab treatment, and outcome.

Results: We have found 66 patients treated with natalizumab since 2007 in our center. The majority $(65.2 \%)$ were female, with a mean age of 35 years, and mean disease duration of 9.5 years. Almost all patients (93.9\%) had received a prior multiple sclerosis immunomodulatory therapy. Patients have been treated with natalizumab on an average time of 24 months, with a statistically significant reduction in Annualized Relapse Ratio $(-1.9, p<0.001)$ and Expanded Disability Status Scale score $(-0.8, p<0.001)$. One patient has developed progressive multifocal leukoencephalopathy; other adverse effects have been uncommon.

Discussion: In general, our results fit those earlier reported in other post-marketing studies. Lack of MRI data and retrospective design are the most important limitations of our study.

Conclusion: Our study confirms natalizumab efficacy and safety in the treatment of relapsing-remitting multiple sclerosis in a 'realworld' practice.

Keywords: Multiple Sclerosis; Natalizumab; Treatment Outcome; Antibodies, Monoclonal, Humanized/ adverse effects; Leukoencephalopathy, Progressive Multifocal/chemically induced.

\section{RESUMO}

Introdução: O natalizumab está aprovado no tratamento da Esclerose Múltipla forma surto-remissão em monoterapia. Desde os ensaios pivot que demostraram a sua eficácia, vários estudos confirmaram a redução da Taxa Anualizada de Surtos e o atraso na progressão da incapacidade. No entanto, dados do 'mundo real', nomeadamente em Portugal, são escassos. Com este trabalho pretendemos descrever os dados demográficos e clínicos dos doentes tratados com natalizumab na Clínica de Esclerose Múltipla do Centro Hospitalar São João, na prática clínica diária.

Material e Métodos: Realizámos um estudo retrospetivo incluindo todos os doentes com esclerose múltipla tratados no nosso Centro com natalizumab (expostos $\geq 1$ dose) desde janeiro de 2007 até maio de 2013. Apurámos dados demográficos, das caraterísticas da doença e do tratamento com natalizumab.

Resultados: No nosso Centro, foram tratados 66 doentes com natalizumab desde 2007. A maioria (65,2\%) era do sexo feminino, com idade média de 35 anos e duração média da doença de 9,5 anos. Quase todos (93,9\%) haviam sido expostos a outro imunomodulador para a esclerose múltipla. $O$ tratamento durou em média 24 meses, com redução estatisticamente significativa da Taxa Anualizada de Surtos $(-1,9, p<0,001)$ e EDSS $(-0,8, p<0,001)$. Um doente desenvolveu leucoencefalopatia multifocal progressiva; outros efeitos adversos foram raros.

Discussão: Em geral, os nossos resultados são sobreponíveis aos descritos noutros estudos pós-comercialização. As limitações mais importantes são a ausência de dados imagiológicos e o desenho retrospetivo.

Conclusão: O nosso estudo confirma a eficácia e segurança do natalizumab no tratamento da esclerose múltipla forma surto-remissão na prática clínica.

Palavras-chave: Esclerose Múltipla; Natalizumab; Anticorpos Monoclonais Humanizados/efeitos adversos; Leucoencefalopatia Multifocal Progressiva/induzida quimicamente.

\section{INTRODUCTION}

Natalizumab (Tysabri ${ }^{\circledR}$, Biogen Idec) is a humanized monoclonal antibody, raised against human 4-integrin, which has been licensed as monotherapy for relapsingremitting multiple sclerosis (RRMS) in 2006. In Europe, natalizumab (NZ) has been approved as a second line immunomodulator (IMD) treatment for patients who do not

respond to first line IMD, whereas in the USA it has been approved as a first line therapy for patients with highly active disease.

The approval was based on the results of two doubleblind placebo-controlled trials: the pivotal AFFIRM and the SENTINEL studies. The AFFIRM study compared

1. Neurology Department. Centro Hospitalar São João. Porto. Portugal.

2. Neurology Department. Centro Hospitalar Vila Nova Gaia/Espinho. Gaia. Portugal

3. Neurology Department. Faculty of Medicine. Porto University. Porto. Portugal.

4. Health Sciences Faculty. Fernando Pessoa University. Porto. Portugal.

Recebido: 03 de Dezembro de 2013 - Aceite: 25 de Fevereiro de 2014 | Copyright @ Ordem dos Médicos 2014 
$\mathrm{NZ}$ with placebo in patients who, for the most part, had not received prior MS therapy. ${ }^{1}$ The SENTINEL study compared two groups of patients: one group was treated with $\mathrm{NZ}$ in monotherapy and the other group received NZ in combination with interferon 1a IM. ${ }^{2}$

As a whole, these studies have shown that $\mathrm{NZ}$ reduces the number of new or enlarging $\mathrm{T} 2$ hyperintense and gadolinium-enhancing magnetic resonance (MRI) lesions $(80-90 \%)$, reduces the number of annualized relapses $(81 \%)$ and reduces the risk of progression of disability in RRMS patients (64\%) in two years. ${ }^{3}$ Studies have also confirmed higher efficacy of NZ over interferon or glatiramer acetate in RRMS.

The SENTINEL study settled the first safety concerns about progressive multifocal leukoencephalopathy (PML). During this study, 3 cases were reported, leading to a temporary suspension of drug commercialization. Several post-marketing safety surveillance programs [the TOUCH study (in the USA and Canada), TYGRIS and TOP studies (in Europe) $]^{4}$ ensured the safety and, consequently, the reintroduction of NZ in monotherapy.

Tysabri ${ }^{\circledR}$ RCM was updated after the identification of risk factors for PML (serum anti-JC virus positive antibodies, treatment longer than 2 years and previous immunosuppressant therapy). Therefore, indications were restricted to highly active RRMS patients.

Because patients enrolled in clinical trials are carefully selected and frequently evaluated, real-world data may not fit the results of clinical trials. Therefore, daily practice clinical setting is crucial. This fact explains the significant increasing of 'real-world' data in the last few years.

We intend to describe the patients' cohort treated with NZ, since 2007, in the MS Clinic of Centro Hospitalar São João, based on daily practice. Analyzed variables include demographic data, disease features and safety and efficacy of NZ.

\section{MATERIAL AND METHODS}

We have conducted a retrospective study concerning patients with RRMS diagnosis, who have been treated with NZ (at least one dose) from January 2007 to May 2013.

Information was gathered about: demographic data (sex and date of birth), baseline disease data (year of MS diagnosis, prior IMD treatments, prior Expanded Disability Status Scale (EDSS) score and annualized relapse rate (ARR), NZ treatment data (number of perfusions, adverse effects and reasons for treatment withdrawal), efficacy data (EDSS score at 12 and 24 months after treatment, and ARR after 12 and 24 months of treatment), data after treatment (number of relapses, time to develop relapses and therapeutic option) and results of serology for JC virus DNA (STRATIFY test; first generation).

For statistical analysis, continuous variables were summarized using mean, standard deviation (SD) and median for, whereas categorical variables were summarized using absolute and relative frequencies.

In order to compare ARR and EDSS before and after NZ, we used the T-student test, considering a significance level of $5 \%$. According to Central Limit Theorem (which states that the arithmetic mean of a sufficiently large number of iterates of independent random variables, will be approximately normally distributed), we assume that this population has a statistically normal distribution.

\section{RESULTS \\ Demographic characterization}

We have found 66 patients treated with NZ since 2007 in our center. The majority [43/66 (65.2\%)] were female, with a mean age of 35 years at the beginning of the treatment (range 14-64) and a mean disease duration of 9.5 years (range 1-38).

\section{MS history (Table 1)}

The most frequent clinical MS presentation was a brainstem syndrome [18/66 (27.3\%)], followed by optic neuritis [12/66 (18.2\%)]. The median baseline EDSS score was 4.0 (mean 3.8, range 0-7.5, $n=59$ ). Twelve patients had EDSS lower than 2.0; in thirtytwo patients, the EDSS ranged from 2.0 and 6.0 , whereas fifteen patients had baseline EDSS above or equal to 6.0.

In the year prior to treatment with $N Z$, median ARR was 2.0 (range 0-7.0, mean 2.0).

Almost all patients [60/66 (90.9\%)] had received a prior first line IMD therapy or an immunossupressant (IMS), up to a maximum of three drugs; from these, more than half [35/60 (58.3\%)] had received only one previous drug, all IMDs; $21 / 60$ (35.0\%) had taken two previous drugs (20 IMDs and 1 IMS - mitoxantrone) and a minority [4/60 (6.7\%)] had received a third drug prior to treatment with NZ (2 IMDs e 2 IMS - cyclophosphamide). A few patients [4/66 (6.1\%)] were naïve for MS therapy.

\section{NZ history}

The reasons for starting NZ were lack of efficacy of first line IMD in the majority of cases $(73.8 \%)$, intolerance in $6.6 \%$ (side effects of first line IMD, leading to patients' discontinuation) and both in $13.8 \%$ (Table 2). In the remaining $(6.6 \%)$, NZ was the first drug due to aggressive disease (rapidly evolving severe RRMS defined by 2 or more disabling relapses in one year, and with 1 or more Gadolinium-enhancing lesions on brain MRI or a significant increase in T2 lesion load as compared to a previous recent MRI).

The mean time of exposure to $\mathrm{NZ}$ was 24 months (range 1-65); 31 patients (47.0\%) had received NZ for a period exceeding 24 months (Fig. 1).

The number of new patients throughout the years was variable, increasing from 2007 (7 patients) to 2009 (16 patients) and then decreasing until 2013 (5 patients).

Inclusion of new patients was higher among those diagnosed between the years 2007 and 2009, accounting for $22.6 \%$ of the total included patients.

Effective number of patients per year on NZ (influenced not only by the ratio 'new patients/patients who stopped 
Table 1 - Demographic and baseline disease characteristics

\begin{tabular}{|c|c|}
\hline Variable & $n=66$ \\
\hline \multicolumn{2}{|l|}{ Sex } \\
\hline Female & $43(65.2 \%)$ \\
\hline Male & $23(34.8 \%)$ \\
\hline Mean age, years & 35 \\
\hline Mean time since diagnosis of MS, years & 9.5 \\
\hline \multicolumn{2}{|l|}{ Prior MS treatments } \\
\hline No & $4(6.1 \%)$ \\
\hline Unknown & $2(3.0 \%)$ \\
\hline Yes & $60(90.9 \%)$ \\
\hline One prior treatment & $35 / 60(58.3 \%)$ \\
\hline Two prior treatments & $21 / 60(35.0 \%)$ \\
\hline$>2$ prior treatments & $4 / 60(6.7 \%)$ \\
\hline Interferon 1b SC & $29 / 60(48.3 \%)$ \\
\hline Interferon 1a SC & $16 / 60(26.7 \%)$ \\
\hline Interferon 1a IM & $21 / 60(35.0 \%)$ \\
\hline Glatiramer acetate & $19 / 60(31.7 \%)$ \\
\hline Immunosuppressants & $2 / 60(33.3 \%)$ \\
\hline Mitoxantrone & $1 / 2$ \\
\hline Cyclophosphamide & $1 / 2$ \\
\hline EDSS score at baseline, median / mean & $4.0 / 3.8$ \\
\hline$A R R$ in year prior to $N Z$, mean & $1.9(0-7.0)$ \\
\hline
\end{tabular}

ARR Annualized relapse rate, EDSS Expanded Disability Status Scale, IM intramuscular, MS multiple sclerosis, NZ natalizumab, SC subcutaneous

Table 2 - Natalizumab history

\begin{tabular}{|c|c|}
\hline Reasons to start NZ & $n=66$ \\
\hline Lack of efficacy & $73.8 \%$ \\
\hline Intolerance & $6.6 \%$ \\
\hline Both & $13.8 \%$ \\
\hline Aggressive disease & $6.6 \%$ \\
\hline Mean duration of treatment with NZ, months & 24 \\
\hline \multicolumn{2}{|l|}{ Efficacy } \\
\hline ARR (12 months / 24 months) & $0.09 / 0.18(n=51)$ \\
\hline EDSS (12 months / 24 months, mean) & $3.02 / 3.08(n=37)$ \\
\hline NZ discontinuation & $40(60.6 \%)$ \\
\hline \multicolumn{2}{|l|}{ Reasons for discontinuation } \\
\hline Lack of efficacy & $8 / 40(20.0 \%)$ \\
\hline Risk & $23 / 40(57.5 \%)$ \\
\hline Drug 'holidays' & $3 / 40(7.5 \%)$ \\
\hline PML & $1 / 40(2.5 \%)$ \\
\hline Adverse effects, other than PML & $4 / 40(10.0 \%)$ \\
\hline Other & $2 / 40(5.0 \%)$ \\
\hline Time for discontinuation, median & 24 months \\
\hline Adverse effects & $4(6.1 \%)$ \\
\hline Severe allergic reaction & 2 \\
\hline Toxic hepatitis & 1 \\
\hline Incapacitating arthralgia & 1 \\
\hline PML & 1 \\
\hline
\end{tabular}

NZ natalizumab; PML progressive multifocal leukoencephalopathy

NZ', but also by the treatment duration) increased from 7 in 2007 to 34 in 2010. After that, the number remained stable, with 31 patients being on NZ during 2013 (Fig.1).

Overall, the drug was discontinued in 40/66 patients
(60.6\%). Reasons for discontinuation were mainly the risk of PML [23/40 (57.5\%), based on positive JC virus serology in association with treatment duration $>24$ months], lack of efficacy [8/40 (20.0\%)], adverse effects [4/40 (10.0\%)] 


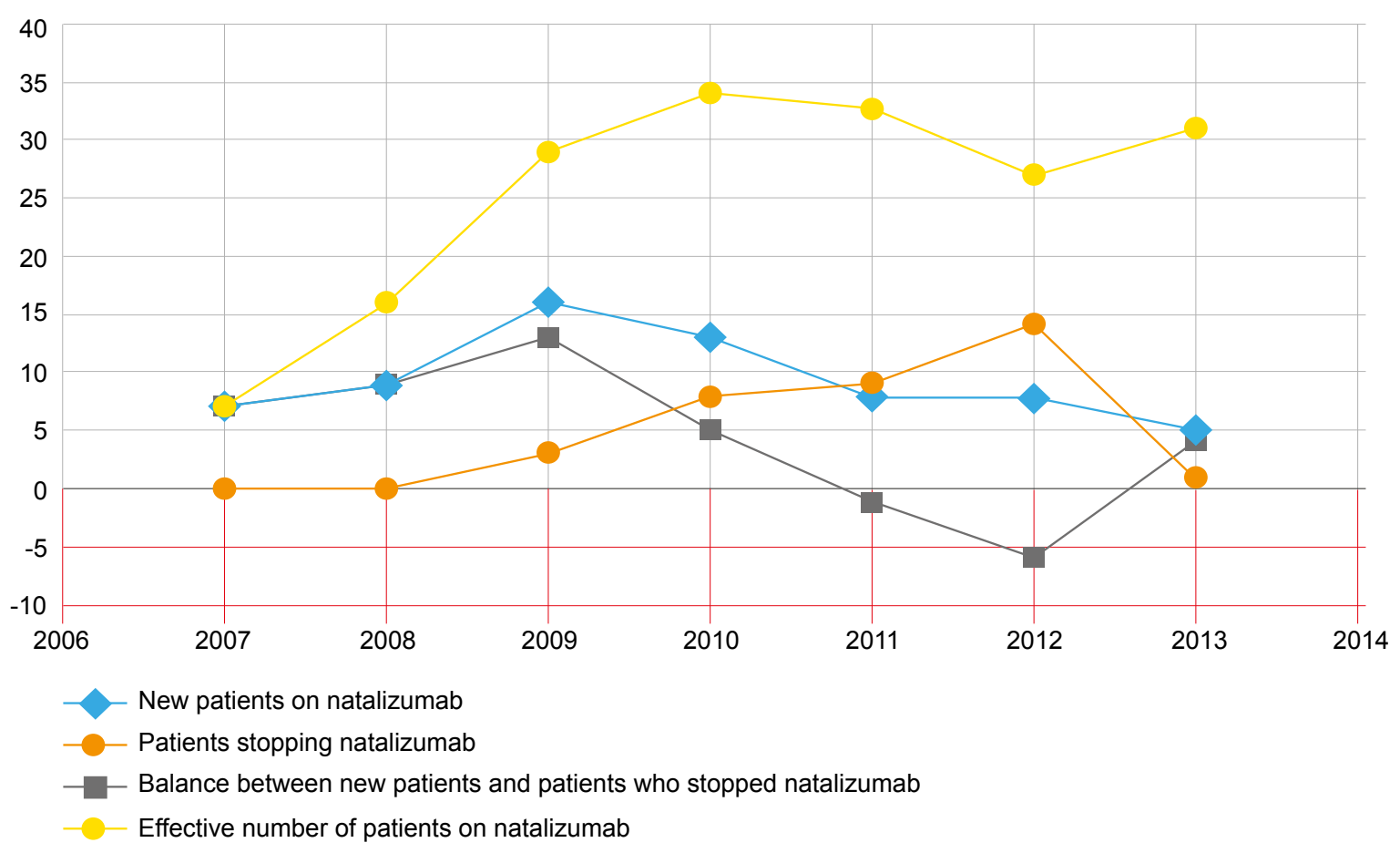

Figure 1 - Variation in number of patients on natalizumab throughout the years

and drug 'holidays' [a temporary suspension determined by gynecological surgery in one and wish of pregnancy in two women, $3 / 40(7.5 \%)]$. Other reasons were pregnancy [1/40 $(2.5 \%)]$ and patients' own decision [1/40 (2.5\%)].

Twenty-three patients were found to have a high PML risk (positive $\mathrm{JC}$ virus serology and $>2$ years of continuous NZ exposure). They had been treated as long as 54 months $(0=3)$, with no complications. Yet, the majority $(18 / 23)$ had stopped NZ before 36 months of exposure.

$\mathrm{JC}$ virus serology in plasma was determined in all but 6 patients, who had already suspended NZ before the STRATIFY test availability, in 2011. This test was performed in a baseline approach in 15 patients and after NZ start in 45 patients. It was positive in 31/60 (51.7\%) and negative in the remaining $[29 / 60(48.3 \%)]$. From those 29 with a negative test, 8 became positive in a next evaluation.

\section{Efficacy outcomes}

For the 53 patients who have completed 12 months of treatment, the median ARR has decreased from 2.0 (in the year prior to treatment) to 0.01 (mean $0.04 ;-1.9$ variation, $p<0.001$ ). At 24 months of treatment, for the 38 patients still exposed, the median ARR has remained 0.0 (mean $0.17)$. It is worth of note that $34 / 38(91 \%)$ of patients have been relapse-free 24 months after NZ.

The EDSS has decreased from a median baseline score of 4.0 (mean $3.8, n=59$ ) to 2.0 at 12 months (mean 3.0, $n=$ 51 ) and 2.5 at 24 months (mean $3.1, n=37$ ). So, the mean difference of EDSS was $-0.8(95 \% \mathrm{Cl}, 0.43-1.14) 12$ months after NZ treatment $(p<0.001)$ and $-0.7(95 \% \mathrm{Cl}, 0.45-1.70)$ 24 months after NZ treatment $(p<0.001)$ (Fig. 2).

Twelve months after NZ, 24 of 57 patients (42.1\%) have improved EDSS score (defined as a decrease of at least 1.0 point, in respect to the total EDSS score and not to any specific functional system contained in the scale). Thirty-two of them (56.1\%) have remained stable (defined as a variation less than 1.0 point) and the remaining [1/57 $(1.8 \%)]$ have got worse (defined as an increase of at least 1.0 point) (Table 3 ).

\section{Adverse effects (Table 2)}

We have observed one case of PML in a positive JC virus patient, after twenty-one continuous monthly infusions, with good outcome (clinical details presented in Discussion).

Other adverse effects imposing NZ suspension have occurred in 4 patients: toxic hepatitis (1); disabling arthralgias (1) and allergic reactions (2). No significant adverse effects related to perfusion itself have been registered.

\section{Evolution after NZ}

Treatment after NZ suspension has been variable. However, the patients have usually returned to a first line IMD (11/30) or they have switched to fingolimod (8/30). Monthly intravenous methylprednisolone (4/30) or human immunoglobulin (5/30), have been other options. For one patient, our choice was azathioprine, since he had a chronic inflammatory bowel disease, and the remaining is not taking any medication (Table 4 ).

Mean ARR 12 months after stopping NZ was 0.53 $(n=17)$. In fact, $11 / 17(64.7 \%)$ have had no relapses, $5 / 17$ $(29.4 \%)$ have had 1 relapse and the other patient have had 4 relapses. Mean time for relapses was 7.5 months (range 2-12 months).

\section{DISCUSSION}

Natalizumab is one of the most recent treatments 


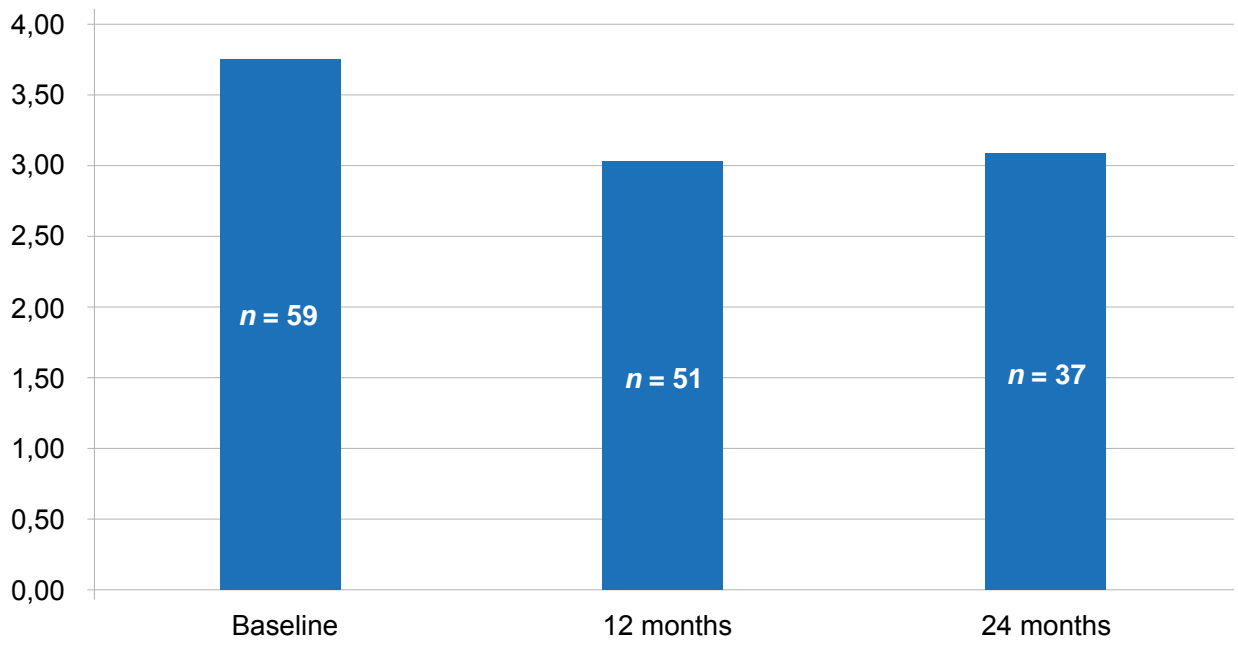

Figure 2 - Mean Expanded Disability Status Scale at baseline, 12 and 24 months after treatment with natalizumab

Table 3 - Disease status 12 months after NZ

\begin{tabular}{lc}
\hline Variable & $n=57$ \\
\hline Improvement & $24(42.1 \%)$ \\
(EDSS decrease $\geq 1$ point) & \\
Stability & $32(56.1 \%)$ \\
(EDSS variation $<1$ point) & \\
Worsening & $1(1.8 \%)$ \\
(EDSS increase $\geq 1$ point) &
\end{tabular}

for RRMS, and its effectiveness has being consistently proved. However, there are safety concerns (primarily regarding $\mathrm{PML})$. In fact, regardless the safety tests before commercialization, some adverse effects may be only evident on post-marketing surveillance, when the drug is ubiquitous in a real-world setting.

In general, our results fit those earlier reported in other post-marketing studies, regarding efficacy and safety. ${ }^{5-11}$ Our data are also consistent with previous findings in terms of baseline patients' profile: age at NZ starting, ARR in the year prior to NZ and clinical MS form. ${ }^{5-11}$ Exception for consistency with other previous findings is made for baseline EDSS and disease duration until NZ, both found to be higher in our study than others 'real-world' studies. ${ }^{5-11}$ It's possible that patients were included too late in the disease evolution; it may be explained by some initial reluctance in NZ prescription, regarding safety concerns, namely PML. On the other hand, this may reflect initial expectations about a new treatment; in fact, when NZ was first licensed in Portugal, it was seen as a last 'hope' for some patients, who were later found to be in a progressive phase of disease. Our patient with the highest EDSS score (7.5) was a 42-year-old woman with a secondary progressive with relapses MS. Treatment decision was based on the ongoing relapses, regardless the treatment with two previous first line IMD and an IMS (cyclophosphamide). However, an effort has been made in our center to enroll patients on NZ earlier in the disease evolution, when inflammatory
Table 4 - After natalizumab

\begin{tabular}{lc}
\hline Variable & $n=30$ \\
\hline Drug of choice & \\
First line IMD & $11(36.7 \%)$ \\
Fingolimod & $8(26.7 \%)$ \\
Monthly methylprednisolone & $4(13.3 \%)$ \\
Monthly IVIG & $5(16.7 \%)$ \\
IMS (Azathioprine) & $1(3.3 \%)$ \\
None & $1(3.3 \%)$ \\
Mean ARR 12 months after stopping NZ & $0.53(n=17)$ \\
no relapses & $11 / 17(64.7 \%)$ \\
1 relapse & $5 / 17(29.4 \%)$ \\
4 relapses & $1 / 17(5.9 \%)$ \\
\hline
\end{tabular}

ARR Annualized relapse rate

component is more active. This option seems reasonable, based on mechanism of action of NZ (antagonism of the 4 subunit of integrin, expressed on the surface of activated T-cells, reducing the inflammation). ${ }^{12}$ Indeed, this is the current tendency, which may help to explain why we have observed a higher percentage of patients with NZ-mediated EDSS score improvement than those previously reported in other cohort studies ${ }^{6}$ and post hoc analyses from the AFFIRM trial. ${ }^{13}$

Our youngest patient was a 14 years-old girl, making NZ an off-label treatment (authorized by Ethics Committee of Centro Hospitalar São João). Our option was based on the severity of the disease and on the inefficacy of other drugs. Indeed, she had had a brainstem syndrome when she was 11; at that time, MRI revealed multiple lesions (probably demyelinating in nature), and the cerebrospinal fluid (CSF) showed a positive pattern of oligoclonal bands. She totally recovered with methylprednisolone. However, in the next 12 months, she had 3 more relapses (2 long pathways and 1 brainstem syndrome). At that time she was sent to our Clinic; she was diagnosed with RRMS and treatment with interferon $-1 b$ was started. However, relapses continued to occur every other month. Plasma exchange and add-on IVIG were tried, but they were inefficacious, both clinically 
and radiologically: the patient had more relapses, disability was increasing and MRI revealed multiple new gadoliniumenhancing lesions in the brain and in the spinal cord. So, after her parents' consent, we decided to escalate therapy, moving to NZ. In addition to stop having relapses, she partially recovered from disability (current EDSS = 2), without NZ-related side effects.

Overall, NZ was well tolerated among our patients and most of the adverse effects were non-severe. The patient who developed a toxic hepatitis had started another drug (amantadine) some weeks before; therefore it remains the doubt about which drug was responsible for this reaction. However, there have been post-market reports of liver lesion in patients taking NZ. ${ }^{16}$

Our case of PML occurred in a 32 year-old male patient, who had previously been treated with interferon $-1 b$ (no history of IMSs). He had started NZ in 2010 due to inefficacy of first line IMD. Serology for JC virus DNA was known to be positive in 2011, when the STRATIFY test has become available. After 21 consecutive monthly infusions, he has developed a left hemiparesis without cognitive or behavioral changes, raising the suspicion of a new relapse. Nevertheless, the progressive motor worsening and lack of improvement with methylprednisolone $1 \mathrm{~g} /$ day for 8 days have lead to PML suspicion and immediate NZ suspension. An urgent brain MRI was highly suspicious for PML, revealing one new diffuse cortico-subcortical right frontal lesion with no gadolinium enhancement or mass effect. In spite of a first negative CSF analysis for JC virus DNA (412 copies/ml of JC virus DNA has been confirmed in a second CSF analysis), he was treated with plasma exchange for five consecutive days, then with methylprednisolone $1 \mathrm{~g}$ for 5 days followed by prednisolone $1 \mathrm{mg} / \mathrm{Kg}$, oral tapering, and mirtazapine (45 mg/day). Patients' symptoms have progressively worsened and, since the PML diagnosis, four high-dose methylprednisolone pulses have been performed. Serial MRIs have remained stable until January 2013. At that time, a gadolinium-enhancement lesion was observed due to a late immune reconstitution inflammatory syndrome. This patient also has presented focal motor seizures, responsive to levetiracetam $2 \mathrm{~g} /$ day and clonazepam $4 \mathrm{mg} /$ day. The neurological deficits are now stabilized (EDSS 5.5) nevertheless he is still being treated with prednisolone 40mg/day. We stress the good outcome of this patient, possibly related to a precocious PML clinical suspect and treatment. Despite the absence of specific recommendations for PML in NZ-treated patients, the therapeutic strategy - based on reports from other MS Centers and in the experience got with PML developed in the context of human immunodeficiency virus infection has revealed successful in this case (presented at Second International Porto MS Congress 2013). ${ }^{17}$

We are aware that the lack of MRI data is a limitation of our study. Still, we have decided to not include it, given that MRI is not exclusively performed inside our hospital (which means different equipments and protocols), making the comparison between exams poorly feasible.

The retrospective design is another obvious limitation of our study. Yet, inherent systematic bias may have been limited since all the information was collected from medical records rather than from patient recall.

Finally, these 'real-world' studies, performed outside the controlled setting of clinical trials, are very informative and probably closer to the clinical practice.

\section{CONCLUSION}

In our series of patients treated with $\mathrm{NZ}$, on an average time of 24 months, there was a statistically significant reduction in ARR (-2 relapses/year) and EDSS (-1 point). Adverse effects were uncommon, although we had a case of PML. Our study confirms the previous data on NZ safety and efficacy in the treatment of RRMS in daily clinical practice.

\section{ACKNOWLEDGMENTS}

The authors thank the staff of the MS Clinic of Centro Hospitalar São João, Porto, for making clinical data available, namely Jorge Reis, Teresa Mendonça and Joana Guimarães and nurse Fátima Lopes. The authors are also grateful to Miguel Semblano for statistical analysis.

\section{CONFLICTS OF INTEREST}

The authors declared no conflicts of interest.

\section{FUNDING SOURCES}

This original work was not financed in any way.

\section{REFERENCES}

1. Polman $\mathrm{CH}$, O'Connor PW, Havrdova E, Hutchinson M, Kappos L, Miller $\mathrm{DH}$, et al. A randomized, placebo-controlled trial of $\mathrm{NZ}$ for relapsing multiple sclerosis. N Engl J Med. 2006;354:899-910.

2. Rudick RA, Sandrock A. NZ: alpha 4-integrin antagonist selective adhesion molecule inhibitors for MS. Expert Rev Neurother. 2004;4:57180.

3. Havrdova E, Galetta S, Hutchinson M, Stefoski D, Bates D, Polman CH, et al. Effect of NZ on clinical and radiological disease activity in multiple sclerosis: a retrospective analysis of the NZ Safety and Efficacy in Relapsing-Remitting Multiple Sclerosis (AFFIRM) study. Lancet Neurol. 2009;8:254-60.

4. Panzara MA, Bozic C, Belcher G, Dong-Si T, Kim R, Hyde R, et al. Natalizumab utilization and safety in patients with relapsing MS in the post-marketing setting. Dusseldorf: ECTRIMS; 2009.

5. Oturai $A B$, Koch-Henriksen N, Petersen T, Jensen PE, Sellebjerg F,

Sorensen PS. Efficacy of natalizumab in multiple sclerosis patients with high disease activity: a Danish nationwide study. Eur J Neurol. 2009;16:420-3

6. Putzki N, Yaldizli O, Mäurer M, Cursiefen S, Kuckert S, Klawe C, et al. Efficacy of natalizumab in second line therapy of relapsing-remitting multiple sclerosis: results from a multi-center study in German speaking countries. Eur J Neurol. 2010;17:31-7.

7. Putzki N, Yaldizli O, Bühler R, Schwegler G, Curtius D, Tettenborn B, et al. Natalizumab reduces clinical and MRI activity in multiple sclerosis patients with high disease activity: results from a multicenter study in Switzerland. Eur Neurol. 2010;63:101-6.

8. Outteryck O, Ongagna J, Zéphir H, Fleury MC, Lacour A, Blanc F, et al. Demographic and clinic characteristics of French patients treated with natalizumab in clinical practice. J Neurol. 2010;257:207-11.

9. Belachew S, Phan-Ba R, Bartholomé E, Delvaux V, Hansen I, Calay 
$\mathrm{P}$, et al. Natalizumab induces a rapid improvement of disability status and ambulation after failure of previous therapy in relapsing-remitting multiple sclerosis. Eur J Neurol. 2011;18:240-45.

10. Holmen C, Piehl F, Hillert J, Fogdell-Hahn A, Lundkvist M, Karlberg E, et al. A Swedish national post-marketing surveillance study of natalizumab treatment in multiple sclerosis. Mult Scler. 2011;17:708-19.

11. Sangalli F, Moiola L, Bucello S, Annovazzi P, Rizzo A, Radaelli M, et al. Efficacy and tolerability of natalizumab in relapsing-remitting multiple sclerosis patients: a post-marketing observational study. Neurol Sci. 2010;31:S299-302.

12. Léger OJ, Yednock TA, Tanner L, Horner HC, Hines DK, Keen S, et al. Humanization of a mouse antibody against Lhuman alpha-4 integrin: a potential therapeutic for the treatment of multiple sclerosis. Hum Antibodies. 1997;8:3-16.

13. Munschauer F, Giovannoni G, Lublin F; O'Connor P; Phillips JT; Polman $\mathrm{C}$, et al. Natalizumab significantly increases the cumulative probability of sustained improvement in physical disability. Montreal: ACTRIMS/ ECTRIMS/LACTRIMS; 2008.

14. Calabresi PA, Giovannoni G, Confavreux C, Galetta SL, Havrdova E, Hutchinson $M$, et al. The incidence and significance of anti-natalizumab antibodies: results from AFFIRM and SENTINEL. Neurology. 2007;69:1391-1403.

15. Goodman AD, Rossman H, Bar-Or A, Miller A, Miller DH, Schmierer K, et al. GLANCE: results of a phase 2, randomized, double-blind, placebo controlled study. Neurology. 2009;72:806-81.

16. Bezabeh S, Flowers $\mathrm{CM}$, Kortepeter $\mathrm{C}$, Avigan M. Clinically significant liver injury in patients treated with natalizumab. Aliment Pharmacol Ther. 2010;31:1028-35.

17. Rocha H, Sá MJ, Abreu P. Progressive multifocal leukoencephalopathy in a low-risk MS patient treated with natalizumab. Second International Porto MS Congress. Sinapse 2013;13:135. 


\section{Multiple Sclerosis Treatment with Natalizumab: Analysis of a Hospital-Based Cohort \\ Acta Med Port 2014:27:437-443}

Publicado pela Acta Médica Portuguesa, a Revista Científica da Ordem dos Médicos

Av. Almirante Gago Coutinho, 151

1749-084 Lisboa, Portugal.

Tel: +351218428 215

E-mail: submissao@actamedicaportuguesa.com

www.actamedicaportuguesa.com

ISSN:0870-399X | e-ISSN: 1646-0758

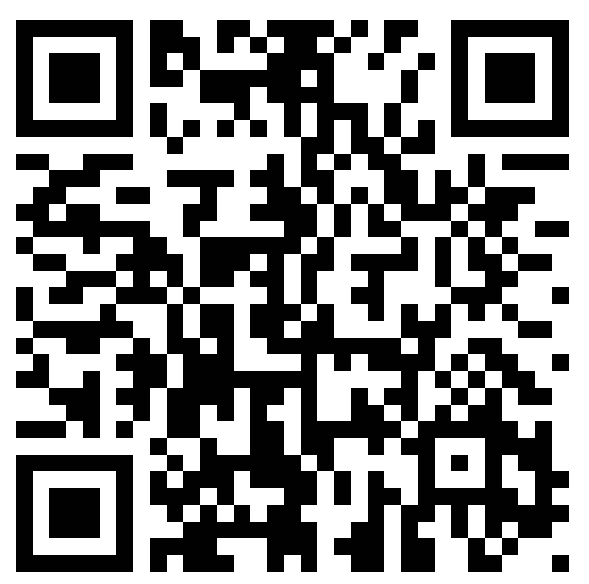

